\title{
Viewpoint: Forage and Range Research Needs in the Central Great Plains
}

\author{
K.P. VOGEL, H.J. GORZ, AND F.A. HASKINS
}

\section{Abstract}

In the central Great Plains, pastures and rangelands often are not economically competitive with grain crops. This has led to increases in acreages of row crops at the expense of rangelands, pastures, and hay crops on marginal lands resulting in severe erosion problems. The productivity of forages, pastures, and rangelands needs to be increased to levels that would make them economically competitive with grain crops. Innovative research will be needed to develop the required knowledge and technology upon which productivity increases can be based. Pastures and rangelands in this area are usually components of production systems which may also include the feeding of hay, silage, crop residues, and other feeds. Coordinated research teams need to be formed that can focus on all components of these production systems. Research needs and objectives of these research teams can be categorized by the land capability classes of the three major ecological regions in this area, the tall-grass, mid-grass, and short-grass prairie. In all of these regions, a classification system that is production-oriented rather than climax-oriented is needed for both pastures and rangelands if effective control of soil erosion and optimal income per land unit are to be achieved. Interstate cooperation in establishing a research team for major ecological region would facilitate the most efficient use of research resources.

Increases in the productivity of pastures and rangelands have been small in comparison to the increases that have been achieved with grain crops. This difference in the increase in productivity can be attributed in part to the small percentage of total research funds that have been allocated to forages.

Because of differences in profitability between forage and grain crops, pastures and rangelands in many instances are not economically competitive with grain crops (Wight et al. 1983). This has led to increased acreage of row crops at the expense of pasture and hay crops on marginal lands, resulting in severe erosion problems (Larson et al. 1983). Extensive areas of range and pasture land in the Great Plains have been plowed in recent years for use in both dryland and irrigated crop production (Laycock 1983, Powers et al. 1983).

The philosophy that native climax vegetation is optimal may have contributed to the plateauing of rangeland productivity and limited productivity to that level. This doctrine also has tended to discourage creative research on rangelands because research has been focused on management towards climax, and suggestions that other concepts and research approaches may be required (Love 1961) have been viewed as heresy (Dyksterhuis 1962, Sampson and Burcham 1963).

Pastures and rangelands in the central Great Plains are usually components of production systems which may also include the feeding of green chop, hay, silage, haylage, and crop residues. A

Authors are supervisory research geneticist, USDA/ARS; supervisory research geneticist, USDA/ARS; and George Holmes professor of agronomy, Univ. of Nebraska, Lincoln 68583.

This is a contribution from the USDA/ARS and the Nebraska Agr. Exp. Sta., Lincoln. Published as paper no. 7428, Journal Series, Nebraska Agr. Exp. Sta. The opinions expressed in this article are those of the authors and not necessarily those of their employing agencies. The authors' primary areas of research are plant breeding and genetics.

The authors wish to express their appreciation to the Journal of Range Management editors and reviewers for their thoughtful and thorough review of this manuscript and their constructive suggestions.

Manuscript accepted January $21,1985$. large percentage of the beef production units in this area are integrated rangeland-cropland units (Wight et al. 1983). Past research has focused on various units of the systems, and the lack of coordinated study of all system components has limited overall gains in productivity. Previous reports on range research needs in the Great Plains have either focused on the range component of the forage production system (Klemmedson et al. 1978) or they have not targeted production goals in terms of alternate uses of land (Great Plains Agr. Comm. 1976, SEA-AR 1981).

Increased productivity of forage crops, particularly pastures and rangelands, in the central Great Plains, is essential because a large proportion of the nation's beef is produced in this area. This region is also one of the nation's areas that is most susceptible to soil erosion. It was part of the 'dust bowl' in the 1930's. Most of the land in this area, including rangelands, is privately owned, and profits, not good intentions, pay the taxes.

The productivity of forages, pastures, and rangelands must be increased to a level that is economically competitive with grain crops grown on the same land. In the past, farmers have been paid by government set-aside programs to put land subject to erosion into grasslands. However, as soon as grain prices increased, these lands were plowed. One way to prevent this cycle from repeating itself is to make forages, pastures, and rangelands more profitable. Profitability is dependent upon productivity and input costs. Increases in productivity on forage-producing lands can be achieved by the use of improved, highly productive forage plants with improved forage quality and increased disease and pest resistance, and by the use of improved, integrated management systems. Innovative research is required to develop the required knowledge and technology. This research should be conducted in coordinated team research programs on all components of the production system. Cooperative efforts involving teams at various locations will enhance research progress. The profitability and erodability of land units can be classified by land capability classes (Klingebiel 1958). Forage, pasture, and range research can be linked to land capability classes since the type of forage crops that can be profitably grown on a unit of land is usually dependent upon the capability classification of that land.

In the central Great Plains, most class I and II land has been and will continue to be used for grain production. In general, forages that can economically compete with cash crops on this land are alfalfa, corn for silage, forage sorghums, sorghum-sudangrass hybrids, and sudangrass. Research on forages for class I and II land should emphasize these crops. Extensive research is being done with alfalfa as a harvested forage but much more could be done to improve this valuable, soil-improving crop as a pasture and range plant.

Corn is both a major grain and forage crop. Most of the current research on corn is for use as a grain crop. Corn produces a high quality silage because of its high grain content. Its value as a forage could be improved if the forage quality of the stover component of the silage were also improved. This could be done by developing improved germplasm and with better ensiling procedures. It appears that minimal effort is being devoted to breeding improved corn hybrids for use as corn silage. The stover of corn grown for grain also is used extensively as livestock feed, particularly for wintering beef cows. Research is needed to improve stover quality. 
A team approach, involving geneticists, forage quality scientists, and ruminant nutritionists, will be required to make maximum progress in improving corn for use as a forage crop.

Sudangrass, sorghum-sudangrass hybrids, and forage sorghums are important forage crops in the central Great Plains because of their drought tolerance. Their importance as forage crops will probably increase in the future because of declining water levels in the Ogallala aquifer which supplies most of the ground water for irrigation in large areas of the Great Plains. Research on developing improved sudangrasses, sorghum-sudangrass hybrids, and forage sorghums is limited. Additional efforts to improve the productivity and quality of these forages, as measured in terms of improved animal performance, are needed.

Class III and IV land moves in and out of forages as the relative prices of grain and livestock change (Wight et al. 1983). Class III land can be used for grain crops if conservation tillage and other conservation practices are used. Class IV land should be kept in permanent pastures but is frequently cultivated when grain prices are high. Perennial grasses and legumes need to be developed for both classes of land that are productive enough so that they are as profitable as grain crops even when the price of grain is high. This is an attainable research objective. To be competitive, these forage plants must be capable of being established in one growing season and must produce forage yields during the first season that are at least $50 \%$ of full production, which must be achieved during the second growing season. This productivity goal can be reached by the development and use of strains with improved establishment capability and by reducing competition from all other sources including weeds and insects. This rapid establishment capability already has been achieved by using atrazine as a pre-emergence herbicide to establish switchgrass (Panicum virgatum L.) and big bluestem (Andropogon gerardi Vitman) (Martin et al., 1982) and is highly feasible with other warm-season grasses having seedling atrazine tolerance (Bahler et al., 1984). Currently, technology is available to double the productivity of many pastures and rangelands, but to be competitive with grain crops, the productivity of forage plants on class III and IV land will have to exceed that which is possible with current technology. This goal can be achieved by developing improved germplasm with the potential for increased yields, quality, and insect and disease resistance and by concurrently developing management systems that will maximize the expression of this genetic potential. This research will require the input of plant breeders and geneticists, forage quality scientists, entomologists, plant pathologists, soil scientists, and animal nutritionists.

The productivity of class V-VII land can also be greatly improved. Unmodified class V, VI, and VII land is usually described as rangeland. Rangeland occupies up to one-half of the total land area of some states in the central Great Plains. Rangeland improvement has been hindered by the criteria currently used to classify range conditions which place native 'climax' vegetation in the 'best'category. Progress in improving the productivity of rangelands could be enhanced if it were generally recognized that rangeland is simply a class of agricultural land for which superior plants can be developed (Love 1961). Wilson and Tupper (1982) have described a system of classifying rangelands that establishes productivity and soil stability as the criteria for determining range conditions. Based on these criteria, they describe the following rangeland conditions:

1) excellent condition: soil stable, productivity good;

2) good condition: soil stable, productivity diminished;

3) fair condition: soil unstable, productivity good;

4) poor condition: soil unstable, productivity diminished.

This production-oriented classification system is needed to improve the productivity of privately owned pasture and rangeland, and it should be adopted as the basis for planning range research and for implementing conservation practices. Greater productivity and profitability would make the return per unit of land in permanent forages more competitive with alternate land uses such as cultivation for dryland wheat production. Climax vegetation may be the type of vegetation that will be the most productive in many areas but this assertion should be based on research and not on philosophy.

In the near future, it is highly likely that herbicides will be developed that will make it possible to economically seed improved grasses and legumes directly into rangelands without plowing. Drills capable of seeding directly into unplowed rangelands are already available. Adapted grasses and legumes that are more productive than native range plants could then be seeded without soil loss. Again the grasses and legumes must be capable of being established in one growing season. Breeding range grasses and legumes for improved yield and quality could lead to doubling beef production per acre. A new switchgrass variety with $6 \%$ higher in vitro dry matter digestibility (IVDMD) than a standard variety produced $35 \%$ more beef per land unit over a two-year period in Nebraska even though the two strains.produced the same amount of forage (Ward et al. 1984). Further increases in yield and quality can be made in switchgrass and other grasses.

Improved management practices could add additional gains in productivity. If soil fertility is the major limiting factor, fertilization can greatly improve productivity. To maximize productivity per land unit, both improved grasses and legumes will be needed. Ideally, rangeland managers need to have the capability to remove undesirable species with herbicides or biological agents and to replace them with improved cultivars of desirable plants without damaging existing desirable species. Improved cultivars can be developed from native climax species or introduced species that have resilience to climatic fluctuations similar to that of native climax vegetation.

The use of complementary forages and reseeded pastures and rangeland to improve productivity and profitability of livestock production units is well documented (Cordingly and Kearl 1975, Rogler and Lorenz 1983, Hart et al. 1983, Mcllvain and Shoop 1973, Grey 1973). New research developments should be evaluated in terms of their overall effects on production systems in addition to their effects on components of those systems, i.e., pasture, hay, or range. In addition to research on plants, there also is a need for research on animal-plant interactions. This includes investigations of grazing systems and genetic research with animals to develop strains that are more productive than current breeds as measured in terms of meat produced per land unit. The current interest in unconventional grazing systems is encouraging, but verifiable research results and not unsubstantiated opinions should be the basis for designing and implementing grazing systems.

It is obvious that expanded forage and range research efforts will be required to make the necessary scientific breakthroughs. Research is expensive and the more complex and difficult the problem, the greater the cost to solve that problem. It is unlikely that individual states, many of which have small populations and modest research budgets, will have the resources to develop the necessary research teams. Public officials and private citizens need to recognize that these are regional problems and that funding should be pooled to establish the required teams. Since there are three major ecological regions in this area, the tall-grass, midgrass, and short-grass prairie (Carpenter 1940), it seems likely that the most research progress could be made if research teams were developed for each region. This need for interdisciplinary research teams was documented in a previous review of range research in the western United States (SEA-AR, 1981). Cooperation among all public research agencies will need to be improved at all levels of management to permit the establishment of these research teams.

\section{References}

Bahler, C.C., K.P. Vogel, and L.E. Moser. 1984. Atrazine tolerance in warm-season grass seedlings. Agron. J. 76:891-895.

Carpenter, J.R. 1940. The grassland biome. Ecol. Monogr. 10:617-684. 
Cordingly, R.V., and G.W. Kearl. 1975. Economics of range reseeding in the plains of Wyoming. Univ. of Wyoming. Agr. Exp. Sta. Research J. 98.

Dyksterhuis, E.J. 1962. Letter to the editor. J. Range Manage. 15:295-296.

Great Plains Agricultural Committee. 1976. Range research needs in the Great Plains. Great Plains Ag. Cou. Pub. 79.

Grey, J.R. 1973. Characteristics of superior management for efficient calf production. p. 11-I15. In: Great Plains Beef Symposium. Great Plains Agr. Publ. No. 63.

Hart, R.H., J.W. Waggoner Jr., D.H. Clark, C.C. Kaltenbach, J.A. Hager, and M.B. Marshall. 1983. Beef cattle performance and crested wheatgrass plus native range vs. native range alone. J. Range Manage. 36:38-40.

Klemmedson, J.O, R.D. Pieper, D.D. Dwyer, W.F. Mueggler, and M. Trlica. 1978. Research needs on western rangelands. J. Range Manage. 31:4-8.

Klingebiel, A.A. 1958. Soil survey interpretation-capability groupings. Soil Sci. Soc. Proc. 22:160-163.

Larson, W.E., F.J. Pierce, and R.H. Dowdy. 1983. The threat of soil erosion to long-term crop production. Science 219:458-465.

Laycock, W.A. 1983. Symposium on the plowing of fragile grasslands in Colorado. Introduction to the problem. Rangelands 5:61 (abstract).

Love, R.M. 1961. The range-natural plant communities or modified ecosystems. J. Brit. Grassl. Soc. 16:89-99.
Martin, A.R., R.S. Moomaw, and K.P. Vogel. 1982. Warm-season grass establishment with atrazine. Agron. J. 74:916-920.

Mcllvain, E.H, and M.C. Shoop. 1973. Use of farmed forage and tame pasture to complement native range. p. L1-L19. In: Great Plains Beef Symposium. Great Plains Agr. Publ. No. 63.

Powers, W.L., B.L. Blad, C.R. Fenster, P.H. Gessaman, J.W. Goeke, D.R. Hay, G.L. Hergenrader, G.W. Hergert, W.L. Miller, J.T. Nichols, and G.W. Rehm. 1983. IANR Sandhills Task Force Report. Nebraska Water Resources Center. Univ. of Nebraska.

Rogler, G.A., and R.J. Lorenz. 1983. Crested wheatgrass-early history in the United States. J. Range Manage. 36:91-93.

Sampson, A.W., and L.T. Burcham. 1963. A critique of a philosophy on range land use. In: Letters to the editor. J. Range Manage. 16:287-290.

Science and Education Administration, Agricultural Research, U.S. Dep. of Agriculture. 1981. SEA-AR range research assessment, western United States. SEA-AR Adm. Report.

Ward, M.G., J.K. Ward, B.E. Anderson, K.P. Vogel, R. Britton, F.A. Haskins, and H.J. Gorz. 1984. Effect of switchgrass digestibility on animal performance. J. Anim. Sci. 59 (Suppl. 1) (Abstr.) 385:303.

Wight, J.R., C.K. Gee, and R.J. Kartchner. 1983. Integrated rangeland and cropland management, p. $435-460$. In: H.E. Dregne and W.O. Willis (eds.) Dryland agriculture. Agron. Monogr. No. 23. ASA.

Wilson, A.D., and Y.J. Tupper. 1982. Concepts and factors applicable to the measurement of range conditions. J. Range Manage. 35:684-689. 